\title{
Minichromosome maintenance 2 (MCM2) immunoreactivity in stage III human gastric carcinoma: clinicopathological significance
}

\author{
Naruo Tokuyasu ${ }^{1}$, Kohei Shomori ${ }^{1}$, Keisuke Nishihara ${ }^{1}$, Hiroki Kawaguchi ${ }^{3}$, Shinji Fujioka ${ }^{1}$, \\ Kensaku Yamaga ${ }^{1}$, Masahide Ikeguchi ${ }^{2}$, and Hisao Ito ${ }^{1}$ \\ ${ }^{1}$ Division of Organ Pathology, Department of Microbiology and Pathology, Faculty of Medicine, Tottori University, 86 Nishi-cho, \\ Yonago, Tottori 683-8503, Japan \\ ${ }^{2}$ Division of Surgical Oncology, Department of Surgery, Faculty of Medicine, Tottori University, Tottori, Japan \\ ${ }^{3}$ Division of Surgery, Yonago Medical Center Hospital, Tottori, Japan
}

\begin{abstract}
Background. The origin licensing factor minichromosome maintenance 2 (MCM2) has recently been identified as a critical regulator of proliferation in both normal and neoplastic cells. This study examined whether MCM2 expression was of prognostic relevance in patients with stage III gastric carcinoma and whether the expression of this marker showed any correlation with clinicopathological characteristics. In addition, we evaluated whether the expression of this proliferation marker was correlated with that of another marker, Ki-67, in gastric carcinoma.

Methods. We examined the immunohistochemical expression of MCM2, Ki-67, and p53 in 103 surgically removed stage III gastric carcinomas, which consisted of 60 intestinal-type and 43 diffuse-type carcinomas. The labeling indices (LIs) of MCM2 and Ki-67 in cancer cells were compared with clinicopathological characteristics, p53 expression, and overall survival rates.

Results. The mean MCM2 and Ki-67 LIs were $69.1 \pm 11.8 \%$ and $48.2 \pm 14.5 \%$, respectively, in the intestinal carcinomas, and $43.7 \pm 9.9 \%$ and $24.9 \pm 11.0 \%$, respectively, in the diffuse carcinomas. The LIs of these proteins revealed no significant association with clinicopathological characteristics or with p53 expression in the carcinomas. Kaplan-Meier survival curves showed that, in the patients with diffuse carcinoma, those with higher MCM2 LIs had a poorer prognosis $(P<0.05)$, but the MCM2 LI was not correlated with prognosis for those with intestinal carcinoma $(P=0.25)$. Ki-67 expression had no significant correlation with prognosis in either intestinal-type or diffuse-type carcinomas. Multivariate Cox regression analysis confirmed that MCM2 was an independent prognostic factor in patients with diffuse carcinoma.

Conclusion. Our data suggest that MCM2 is a useful prognostic marker in patients stage III diffuse-type gastric carcinoma.
\end{abstract}

Key words Minichromosome maintenance protein 2 $(\mathrm{MCM} 2) \cdot$ Gastric carcinoma $\cdot \mathrm{Ki}-67 \cdot \mathrm{p} 53 \cdot$ Prognostic value

Offprint requests to: $\mathrm{K}$. Shomori

Received: October 19, 2007 / Accepted: January 8, 2008

\section{Introduction}

Gastric carcinoma is ranked as the world's second leading cause of cancer mortality next to lung cancer, with an estimated 800000 new cases and 650000 deaths per year [1]. Growing evidence suggests that chemotherapy may improve disease-free intervals and overall survival $[2,3]$. In this regard, the current high rates of recurrence and subsequent poor survival have prompted the ever-increasing use of multimodal strategies. Therefore, further studies are necessary to refine the list of molecular markers and to identify novel markers for prognostic and predictive purposes.

Differences in kinetic parameters related to DNA replication licensing may be candidates for growth control and, therefore, of importance in carcinogenesis. The initiation of eukaryotic DNA replication is precisely controlled through a core set of licensing factors, including Orc1-6, Cdc6, Cdt1, and minichromosome maintenance (MCM) 2, for seven proteins, during $\mathrm{S}$ phase [4-6]. Licensed replication origins are activated by cyclin-dependent kinases, resulting in the unwinding of the DNA helix and the initiation of DNA synthesis [7]. Replication initiation is tightly coupled to removal of the license, which prevents relicensing after origin firing until mitosis. This step is critical, as origins must fire once, and once only, in each cell cycle, to ensure genomic stability $[8,9]$.

The overexpression of MCM2 protein was reported in a variety of malignant neoplasms in our previous studies, and a possible prognostic significance of the expression in oral and bronchial carcinomas, as well as in soft tumors, was confirmed [10-12]. It is of interest that MCM2 protein has higher sensitivity than Ki-67 for proliferation in cycling and noncycling cells that possess proliferative potential, and this implies that MCM2 protein could be a promising novel marker for proliferation in such cells. 
Only a few studies have examined MCM2 expression in gastric carcinoma, and the prognostic significance of this expression has never been analyzed [13, 14]. The aim of this study was to determine whether the expression of this novel licensing protein, MCM2, might be useful in predicting the potential for tumor proliferation and the outcome for stage III gastric carcinoma, which frequently metastasizes to the liver and peritoneum, and for which the prognosis remains unfavorable [15].

\section{Patients, materials, and methods}

\section{Cell lines and Western blotting}

The expression of MCM2 was examined in eight human gastric carcinoma cell lines: MKN-1, -7, -28, -45, -74, TMK-1, KATO-III, and HSC-39. All of the cell lines were cultured in Dulbecco's modified Eagle's medium supplemented with $10 \%$ fetal bovine serum (FBS; Life Technologies, Grand Island, NY, USA), $100 \mathrm{U} / \mathrm{ml}$ penicillin, $100 \mu \mathrm{g} / \mathrm{ml}$ streptomycin, and $292 \mu \mathrm{g} / \mathrm{ml} \mathrm{L}$ glutamine, at $37^{\circ} \mathrm{C}$ in a humidified atmosphere with $5 \%$ $\mathrm{CO}_{2}$ in air.

The subconfluent cells were rinsed in phosphatebuffered saline (PBS) and solubilized in lysis buffer (150 mM NaCl; $20 \mathrm{mM}$ Tris-HCl, $\mathrm{pH}$ 7.4; 0.1\% sodium dodecyl sulfate [SDS]; $1 \%$ sodium deoxycholate; and $1 \%$ Triton X-100, containing a mixture of proteinase inhibitors [5 $\mathrm{\mu g} / \mathrm{ml}$ aprotinin, $1 \mu \mathrm{g} / \mathrm{ml}$ leupeptin, $1 \mathrm{mM}$ phenylmethylsulfonyl fluoride, and $1 \mathrm{mg} / \mathrm{ml}$ trypsin inhibitor]) for $60 \mathrm{~min}$ on ice. Lysates were centrifuged at $12000 \mathrm{rpm}$ for $5 \mathrm{~min}$. The protein concentrations were determined with the Bradford protein assay (BioRad Laboratories, Hercules, CA, USA), using bovine serum albumin as the standard. Equal amounts $(30 \mu \mathrm{g})$ of proteins were resolved by electrophoresis on $7.5 \%$ polyacrylamide gel and electrotransferred to a polyvinylidene difluoride filter membrane (Immobilon; Millipore, Waltham, MA, USA). After the blocking of nonspecific binding with $10 \%$ skimmed milk in PBS for $1 \mathrm{~h}$ at room temperature, the blotted membrane was incubated with anti-MCM2 (diluted 1:5) mouse monoclonal antibodies, which were generated in our laboratory, and which detect the N-terminal 13 amino acids of MCM2 (amino acids 15-27, LTSSPGRSSRRTD) [1012]. Blots were developed with peroxidase-labeled antimouse IgG antibody (1: 1000; MBL, Nagoya, Japan), using enhanced chemiluminescence (ECL Detection System; Amersham Pharmacia Biotech, Amersham, UK).

\section{Tissue specimens}

Primary stage III gastric carcinoma specimens of 103 patients were divided into intestinal and diffuse types according to the Lauren classification [16]. Intestinaltype carcinomas were obtained from 60 patients and diffuse-type carcinomas were obtained from 43 patients who had undergone curative gastrectomy at the Department of Surgical Oncology, Tottori University and Yonago Medical Center Hospital. No patient had received preoperative chemotherapy or radiotherapy. Histological diagnoses were made on hematoxylin and eosin (H\&E) tissue sections, according to the Japanese classification of gastric carcinoma [17]. All the patients had undergone distal, proximal, or total gastrectomy, with the dissection of level 1 and 2 regional lymph nodes. The follow-up period for survivors was 1-161 months (median, 41 months) after surgery. Informed consent was obtained from all subjects and/or their guardians. This study was approved by the Institutional Review Board at Tottori University, Faculty of Medicine.

\section{Immunohistochemistry}

Tissue sections $(3 \mu \mathrm{m})$ were cut from formalin-fixed, paraffin-embedded tissue blocks and put on microscope slides with a silane coat. They were dewaxed in xylene, rehydrated through a graded series of ethanol solutions, and rinsed in distilled water for $5 \mathrm{~min}$. Then, for antigen retrieval, sections were microwaved in $0.01 \mathrm{~mol} / \mathrm{l}$ sodium citrate buffer ( $\mathrm{pH} \mathrm{6.0)}$ for $20 \mathrm{~min}$ at $95^{\circ} \mathrm{C}$, using a microwave processor (Model MI-77; Azumaya, Tokyo, Japan), and immersed in $0.3 \%$ hydrogen peroxide in methanol for $30 \mathrm{~min}$, to block endogenous peroxidase. After being rinsed in PBS for $5 \mathrm{~min}$, the slides were preblocked with a solution of $2 \%$ normal rabbit serum at room temperature for $20 \mathrm{~min}$, and incubated at $4{ }^{\circ} \mathrm{C}$ overnight with mouse monoclonal antibodies, as follows: anti-MCM2 antibody, anti-Ki-67 antibody (MIB-1, 1: 50; Dako, Glostrup, Denmark), and anti-p53 (1: 50; Dako). A subsequent reaction was initiated by the streptavidin-biotin-peroxidase complex technique (SAB method), using a Histofine SAB-PO (M) Immunohistochemical Staining Kit (Nichirei, Tokyo, Japan). The immunoreaction was visualized with $0.2 \mathrm{mg} / \mathrm{ml} \mathrm{3}$, 3 '-diaminobenzidine tetrahydrochloride and $20 \mu \mathrm{l} / \mathrm{dl}$ hydrogen peroxide in $0.05 \mathrm{M}$ Tris- $\mathrm{HCl}$ buffer ( $\mathrm{pH} 7.6)$. Finally, the slides were counterstained with hematoxylin.

\section{Evaluation of MCM2 and Ki-67 labeling indices (LIs) and 553 expression}

To evaluate MCM2, Ki-67, and p53 expression levels, positively stained tumor-cell nuclei were counted in the most frequently and distinctly labeled areas, containing the periphery and center, and superficial and invasive front. Counts were performed in high-magnification 
fields using the FLOVEL Image Filing System FlvFs (FLOVEL, Tachikawa, Japan). LIs were expressed as the percentage of positively stained cells based on a count of at least 500 tumor cells. The proliferative cells in non-neoplastic mucosa adjacent to carcinoma served as a reliable internal positive control for MCM2 and Ki-67. Lymphoid follicles served as an internal negative control, although only a few lymphoid cells showed immunoreactivity. p53 immunoreactivity was observed in the nuclei of gastric carcinoma cells. All cases were judged to have high expression of p53 when the LI of p53 was more than $10 \%$.

\section{Double-labeling immunofluorescence}

In order to examine the differential expression of MCM2 and Ki-67 in individual specimens, doublelabeling immunofluorescence experiments were performed on paraffin-embedded tissue sections that were deparaffinized, immersed in $10 \mathrm{mM}$ sodium citrate buffer, and microwaved at $95^{\circ} \mathrm{C}$ for $20 \mathrm{~min}$. Subsequently, blocking was carried out with $10 \%$ normal FBS for $15 \mathrm{~min}$. The sections were then incubated overnight at $4{ }^{\circ} \mathrm{C}$ with a mixture of goat anti-MCM2 polyclonal antibody (1: 100; Santa Cruz Biotechnology, Heidelberg, Germany) and anti-Ki-67 antibody (1: 50). Then, they were incubated for $1 \mathrm{~h}$ with rabbit anti-goat $\mathrm{IgG}$ (Nichirei), and for $6 \mathrm{~h}$ at $4{ }^{\circ} \mathrm{C}$ with a mixture of AlexaFluor-488-conjugated anti-rabbit antibody diluted 1 : 200, and Alexa-Fluor-546-conjugated anti-mouse antibody diluted 1: 200 (Molecular Probes, Eugene, OR, USA). After the sections were washed, immunoreactivity was observed with a fluorescence microscope (Eclipse E800; Nikon, Tokyo, Japan).

\section{Statistical analysis}

The association of factors was evaluated by the $\chi^{2}$ test. The significance of differences among means was determined by Student's $t$-test or the Mann-Whitney $U$ - test. Survival rates were estimated by the Kaplan-Meier method, and statistical analysis was carried out by the log-rank test for equality of the survival curves. A Cox proportional hazards model for the risk ratio was used to evaluate survival in a multivariate analysis. The level of significance was set at $P<0.05$.

\section{Results}

MCM2 expression in human gastric carcinoma cell lines

We examined the expression of MCM2 in eight gastric carcinoma cell lines by Western blotting. Figure 1 shows the expression of MCM2 protein in all the cell lines, with a specific single band at $130 \mathrm{kD}$, which indicates the specificity of the anti-MCM2 antibody (2H10) used in this study.

\section{MCM2 and Ki-67 expression in gastric mucosa and carcinoma}

As shown in Fig. 2, MCM2 and Ki-67 were predominantly localized in the nuclei of cells located in the proliferative zone of non-neoplastic mucosa. In contrast, no specific distribution of cells positive for MCM2 and Ki-67 was noted in gastric carcinoma (Fig. 3). In order to examine the expression patterns of MCM2 and Ki-67 in carcinoma cells simultaneously, doublelabeling immunofluorescence experiments were conducted (Fig. 4). All the cells expressing Ki-67 (Fig. 4, green) also expressed MCM2 (Fig. 4, red), and this coexpression gave a yellow signal. No cells showing only green fluorescence were observed among the carcinoma cells, except for mitotic cells that showed immunoreactivity for Ki-67, but not for MCM2. There were variable numbers of MCM2-positive and Ki-67-negative tumor cells with red signals (Fig. 4).

In the 103 stage III gastric carcinomas, the mean MCM2 LI in the 60 intestinal-type carcinomas was 69.1 $\pm 11.8 \%$ (range, $38.7 \%$ to $91.4 \%$ ), and the mean MCM2 LI in the 43 diffuse-type carcinomas was $43.7 \pm 9.90 \%$ (range, $20.1 \%$ to $65.2 \%$ ); the value being significantly higher in the former than in the latter $(P<0.001)$. The mean Ki-67 LI in the 60 intestinal-type carcinomas was $48.2 \pm 14.6 \%$ (range, $14.0 \%$ to $79.5 \%$ ) and the mean Ki-67 LI in the 43 diffuse-type carcinomas was $24.9 \pm 11.0 \%$ (range, $5.3 \%$ to $46.5 \%$ ) the value being

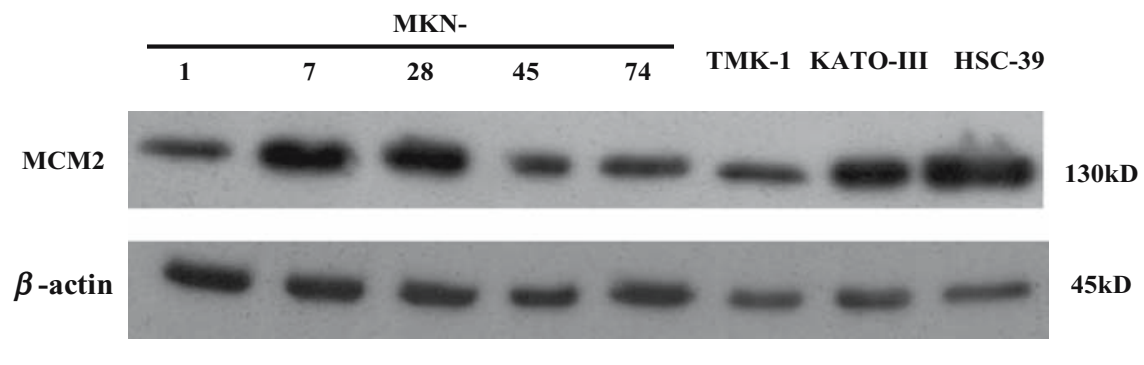

Fig. 1. Western blotting of minichromosome maintenance 2 (MCM2) protein expression in eight human gastric carcinoma cell lines. MCM2 protein was expressed in all of the cell lines, with a specific band at $130 \mathrm{kD}$ 

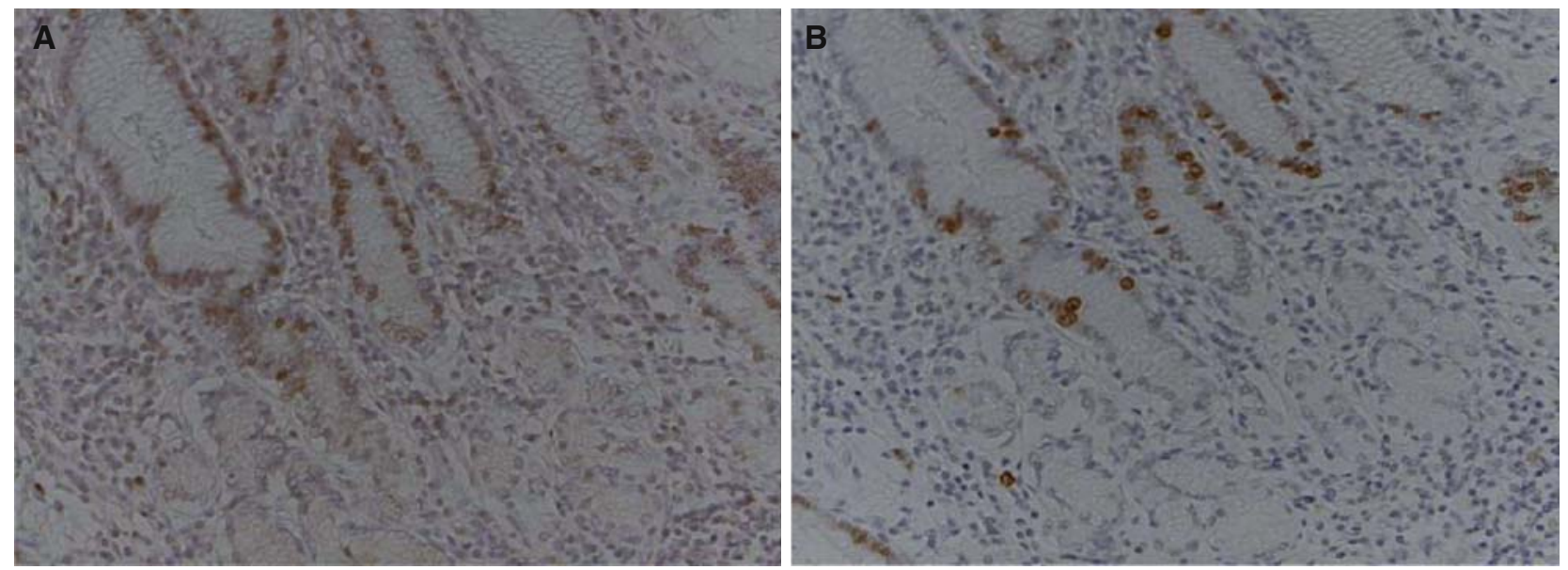

Fig. 2A, B. Immunohistochemistry of MCM2 (A) and Ki-67 (B) in normal gastric mucosa. A and $\mathbf{B}$ are serial sections. MCM2 immunoreactivity was observed in the nuclei of cells located in the proliferative zone of non-neoplastic mucosa. The number of MCM2-positive cells (A) was clearly higher than that of Ki-67-positive cells $(\mathbf{B}), \times 100$
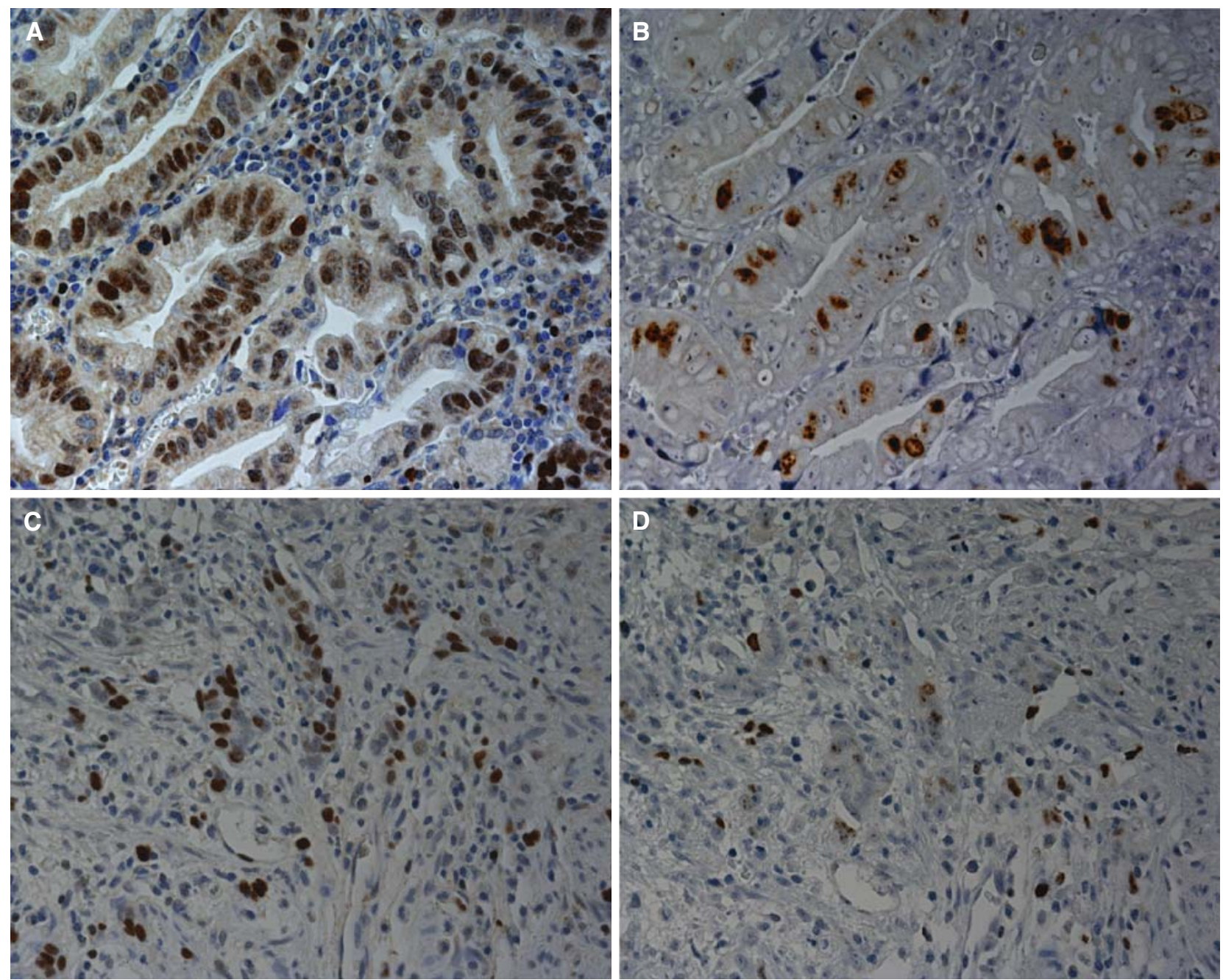

Fig. 3A-D. Immunohistochemistry in intestinal-type $(\mathbf{A}, \mathbf{B})$ and diffuse-type $(\mathbf{C}, \mathbf{D})$ human gastric carcinoma. Nuclear expression of MCM2 $(\mathbf{A}, \mathbf{C})$ and $\mathrm{Ki}-67(\mathbf{B}, \mathbf{D})$ was noted in a high number of tumor cells and in a few lymphoid cells. The

number of MCM2-immunoreactive tumor cells was clearly higher than that of Ki-67-immunoreactive tumor cells. A, B, $\mathbf{C}$, and $\mathbf{D}$ are serial sections, $\times 400$ 
Table 1. Labeling indices (LIs) of MCM2 and Ki-67 in stage III intestinal- and diffusetype gastric carcinoma

\begin{tabular}{|c|c|c|c|c|c|}
\hline & $\begin{array}{c}\text { Number of } \\
\text { cases }\end{array}$ & $\begin{array}{c}\text { MCM2 LI } \\
(\text { mean } \pm \text { SD) }\end{array}$ & $P$ value & $\begin{array}{c}\text { Ki-67LI } \\
(\text { mean } \pm \mathrm{SD})\end{array}$ & $P$ value \\
\hline Intestinal type & 60 & $69.1 \pm 11.8$ & \multirow{2}{*}{$<0.001$} & $48.2 \pm 14.6$ & \multirow{2}{*}{$<0.001$} \\
\hline Diffuse type & 43 & $43.7 \pm 9.90$ & & $24.9 \pm 11.0$ & \\
\hline
\end{tabular}

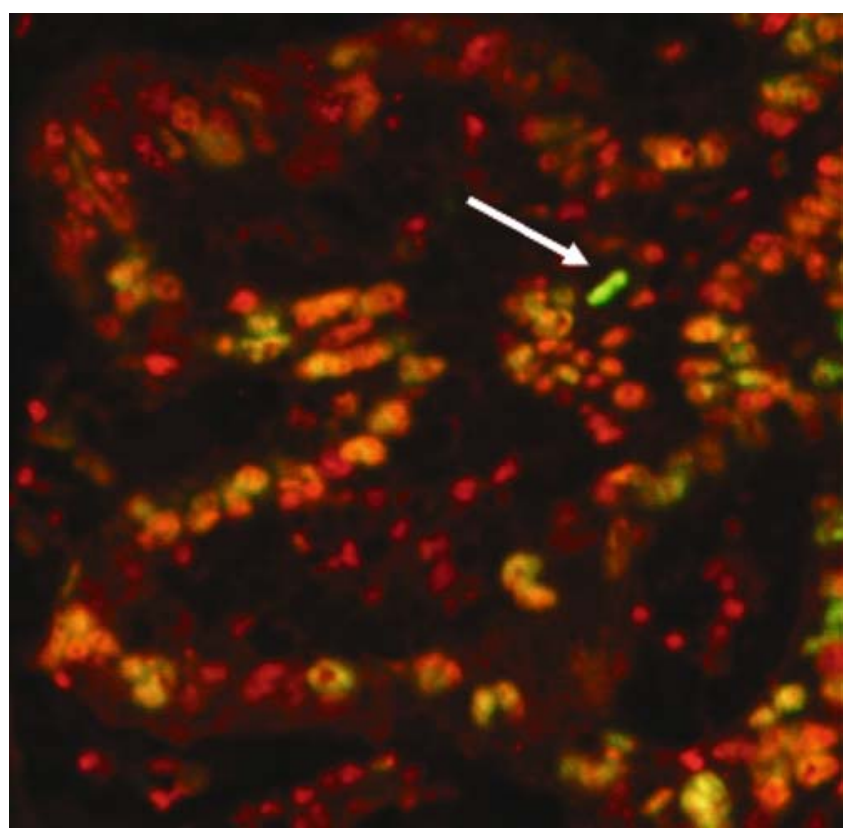

Fig. 4. Double-labeling fluorescence microscopy for MCM2 (red) and Ki-67 (green) in gastric carcinoma. Many cells coexpressed MCM2 and Ki-67 (yellow), although there were a few cells that showed MCM2 expression alone. Arrow indicates mitotic cells showing only Ki-67 expression with a green signal, $\times 400$

significantly higher in the former than in the latter $(P<$ 0.001; Table 1).

The mean LI was significantly higher in MCM2positive than in Ki-67-positive tumor cells, regardless of histological type. The relationship between the MCM2 and $\mathrm{Ki}-67 \mathrm{LIs}$ in gastric carcinoma cells is shown in Fig. 5. A scatter plot indicated that the relationship between the MCM2 and Ki-67 LIs could be modeled as linear. A significant correlation was observed between the MCM2 and Ki-67 LIs $(P<0.0001 ;$ Fig. 5).

Correlation of MCM2 and Ki67 LIs with clinicopathological characteristics and p53 expression

The relationship between the MCM2 and KI-67 LIs and clinicopathological characteristics and p53 expression in gastric carcinoma is summarized in Tables 2 and 3. A comparison of LIs and clinicopathological characteristics for each marker in the intestinal- and diffuse-type

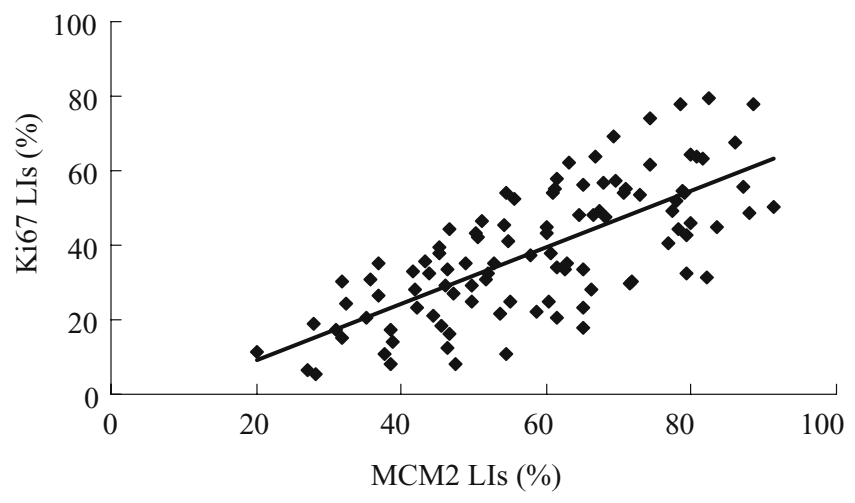

Fig. 5. Pearson's correlation coefficient test for the correlation between MCM2 and Ki-67 labeling indexes (LIs) for all the cases. The MCM2 LI was strongly associated with the Ki67 LI $(r=0.72 ; 95 \%$ confidence interval [CI], 0.61, 0.80; $P<$ $0.0001)$

carcinomas revealed no significant associations with sex, age, histological type, tumor status, lymph node status, lymphatic invasion, or blood vessel invasion.

The mean MCM2 LI was $67.8 \pm 12.2 \%$ in the intestinal-type carcinomas with high expression of p53 $(n=$ 23 ) and it was $70.0 \pm 11.7 \%$ in those with low expression of p53 $(n=37)$, the difference not being significant $(P=0.50)$. Similarly, in the diffuse carcinomas with high expression of p53 $(n=20)$, the mean MCM2 LI was 42.6 $\pm 11.6 \%$ and it was $44.8 \pm 8.23 \%$ in those with low expression of p53 $(n=23)$, the difference also not being significant ( $P=0.13$; Tables 2 and 3$)$. Thus, no correlation was noted between p53 expression and mean MCM2 LI.

\section{Prognostic analysis}

The overall 5-year survival rates were $47 \%$ in the 60 patients with stage III intestinal-type gastric carcinoma and $46 \%$ in the 43 patients with diffuse-type gastric carcinoma (data not shown). The cutoff level of the MCM2 LI in carcinoma cells was set at $69.0 \%$ for intestinal-type carcinoma (high, $n=30$ vs low, $n=30$ ) and at $44.0 \%$ for the diffuse type (high, $n=23$ vs low $n=20$ ), with the values being almost at the median. Similarly, the cutoff level of the Ki-67 LI in carcinoma cells was set at $49.0 \%$ (high, $n=30$ vs low, $n=30$ ) for intestinal- 
Table 2. Relationship between MCM2 and Ki-67 LIs and clinicopathological characteristics and p53 expression in patients with intestinal-type gastric carcinoma

\begin{tabular}{|c|c|c|c|c|c|}
\hline Parameter & $\begin{array}{c}\text { Number of } \\
\text { cases }\end{array}$ & $\begin{array}{c}\text { MCM2 LI } \\
(\text { mean } \pm \text { SD })\end{array}$ & $P$ value & $\begin{array}{c}\text { Ki-67 LI } \\
(\text { mean } \pm \text { SD })\end{array}$ & $P$ value \\
\hline \multicolumn{6}{|l|}{ Sex } \\
\hline Male & 47 & $69.8 \pm 12.7$ & \multirow[t]{2}{*}{0.43} & $48.3 \pm 15.3$ & \multirow[t]{2}{*}{0.94} \\
\hline Female & 13 & $66.9 \pm 7.90$ & & $48.0 \pm 12.6$ & \\
\hline \multicolumn{6}{|l|}{ Age (years) } \\
\hline$<69$ & 30 & $70.5 \pm 9.40$ & \multirow[t]{2}{*}{0.37} & $48.0 \pm 14.6$ & \multirow[t]{2}{*}{0.91} \\
\hline$\geq 69$ & 30 & $67.8 \pm 13.8$ & & $48.4 \pm 14.9$ & \\
\hline \multicolumn{6}{|l|}{ Histological type } \\
\hline pap & 7 & $74.1 \pm 10.6$ & \multirow[t]{4}{*}{0.34} & $51.0 \pm 11.6$ & \multirow[t]{4}{*}{0.78} \\
\hline tub1 & 7 & $59.8 \pm 11.4$ & & $43.2 \pm 17.2$ & \\
\hline tub2 & 26 & $70.3 \pm 13.3$ & & $48.3 \pm 14.8$ & \\
\hline por1 & 20 & $69.9 \pm 8.70$ & & $49.3 \pm 15.4$ & \\
\hline \multicolumn{6}{|l|}{ Tumor status } \\
\hline pT2 & 7 & $72.3 \pm 16.0$ & \multirow[t]{3}{*}{0.24} & $47.4 \pm 14.5$ & \multirow[t]{3}{*}{0.98} \\
\hline pT3 & 47 & $67.8 \pm 11.3$ & & $48.4 \pm 14.4$ & \\
\hline pT4 & 6 & $75.7 \pm 8.59$ & & $47.6 \pm 19.0$ & \\
\hline \multicolumn{6}{|c|}{ Lymph node status } \\
\hline $\mathrm{pN} 1$ & 31 & $69.6 \pm 9.90$ & \multirow[t]{2}{*}{0.74} & $48.1 \pm 13.7$ & \multirow[t]{2}{*}{0.96} \\
\hline $\mathrm{pN} 2$ & 29 & $68.6 \pm 13.7$ & & $48.3 \pm 15.8$ & \\
\hline \multicolumn{6}{|c|}{ Lymphatic invasion } \\
\hline Negative & 4 & $63.9 \pm 13.8$ & \multirow[t]{2}{*}{0.36} & $55.9 \pm 8.31$ & \multirow[t]{2}{*}{0.14} \\
\hline Positive & 56 & $69.5 \pm 11.7$ & & $47.7 \pm 14.9$ & \\
\hline \multicolumn{6}{|c|}{ Blood vessel invasion } \\
\hline Negative & 6 & $73.6 \pm 10.2$ & \multirow[t]{2}{*}{0.42} & $51.9 \pm 16.4$ & \multirow[t]{2}{*}{0.52} \\
\hline Positive & 54 & $68.6 \pm 12.0$ & & $47.8 \pm 14.5$ & \\
\hline \multicolumn{6}{|l|}{ p53 } \\
\hline High $(\geq 10 \%)$ & 23 & $67.8 \pm 12.2$ & \multirow[t]{2}{*}{0.5} & $47.9 \pm 15.1$ & \multirow[t]{2}{*}{0.91} \\
\hline Low $(<10 \%)$ & 37 & $70.0 \pm 11.7$ & & $48.4 \pm 14.5$ & \\
\hline
\end{tabular}

Table 3. Relationship between MCM2 and Ki-67 LIs and clinicopathological characteristics and p53 expression in patients with diffuse-type gastric carcinoma

\begin{tabular}{|c|c|c|c|c|c|}
\hline Parameter & $\begin{array}{c}\text { Number of } \\
\text { cases }\end{array}$ & $\begin{array}{c}\text { MCM2 LI } \\
(\text { mean } \pm \text { SD })\end{array}$ & $P$ value & $\begin{array}{c}\text { Ki-67 LI } \\
(\text { mean } \pm \text { SD })\end{array}$ & $P$ value \\
\hline \multicolumn{6}{|l|}{ Sex } \\
\hline Male & 26 & $42.2 \pm 10.0$ & \multirow[t]{2}{*}{0.89} & $24.2 \pm 11.0$ & \multirow[t]{2}{*}{0.61} \\
\hline Female & 17 & $46.0 \pm 9.40$ & & $26.0 \pm 11.4$ & \\
\hline \multicolumn{6}{|l|}{ Age (years) } \\
\hline$<60$ & 19 & $42.6 \pm 12.8$ & \multirow[t]{2}{*}{0.5} & $24.0 \pm 10.8$ & \multirow[t]{2}{*}{0.65} \\
\hline$\geq 60$ & 24 & $44.7 \pm 6.90$ & & $25.5 \pm 11.3$ & \\
\hline \multicolumn{6}{|c|}{ Lymph node status } \\
\hline $\mathrm{pN} 1$ & 23 & $43.1 \pm 10.7$ & \multirow[t]{2}{*}{0.58} & $24.5 \pm 11.7$ & \multirow[t]{2}{*}{0.8} \\
\hline $\mathrm{pN} 2$ & 20 & $44.1 \pm 9.10$ & & $25.3 \pm 10.4$ & \\
\hline \multicolumn{6}{|c|}{ Lymphatic invasion } \\
\hline Negative & 9 & $44.9 \pm 11.8$ & \multirow[t]{2}{*}{0.68} & $27.6 \pm 11.4$ & \multirow[t]{2}{*}{0.41} \\
\hline Positive & 34 & $43.4 \pm 9.50$ & & $24.1 \pm 11.0$ & \\
\hline \multicolumn{6}{|c|}{ Blood vessel invasion } \\
\hline Negative & 12 & $46.3 \pm 7.70$ & \multirow[t]{2}{*}{0.30} & $24.9 \pm 9.20$ & \multirow[t]{2}{*}{1.00} \\
\hline Positive & 31 & $42.7 \pm 10.5$ & & $24.9 \pm 11.8$ & \\
\hline \multicolumn{6}{|l|}{ p53 } \\
\hline High $(\geq 10 \%)$ & 20 & $42.6 \pm 11.6$ & \multirow[t]{2}{*}{0.13} & $26.9 \pm 10.7$ & \multirow[t]{2}{*}{0.28} \\
\hline Low $(<10 \%)$ & 23 & $44.8 \pm 8.23$ & & $23.1 \pm 11.2$ & \\
\hline
\end{tabular}

type carcinoma and at $24.7 \%$ (high, $n=21$ vs low, $n=$ 22) for the diffuse type, respectively (data not shown).

Kaplan-Meier survival curves showed that there was no significant correlation between MCM2 expression and survival rate in the patients with intestinal-type carcinoma ( $P=0.25$; Fig. $6 \mathrm{~A})$. On the other hand, in the 23 patients with diffuse-type carcinoma with higher MCM2 expression, the prognosis was significantly 
A
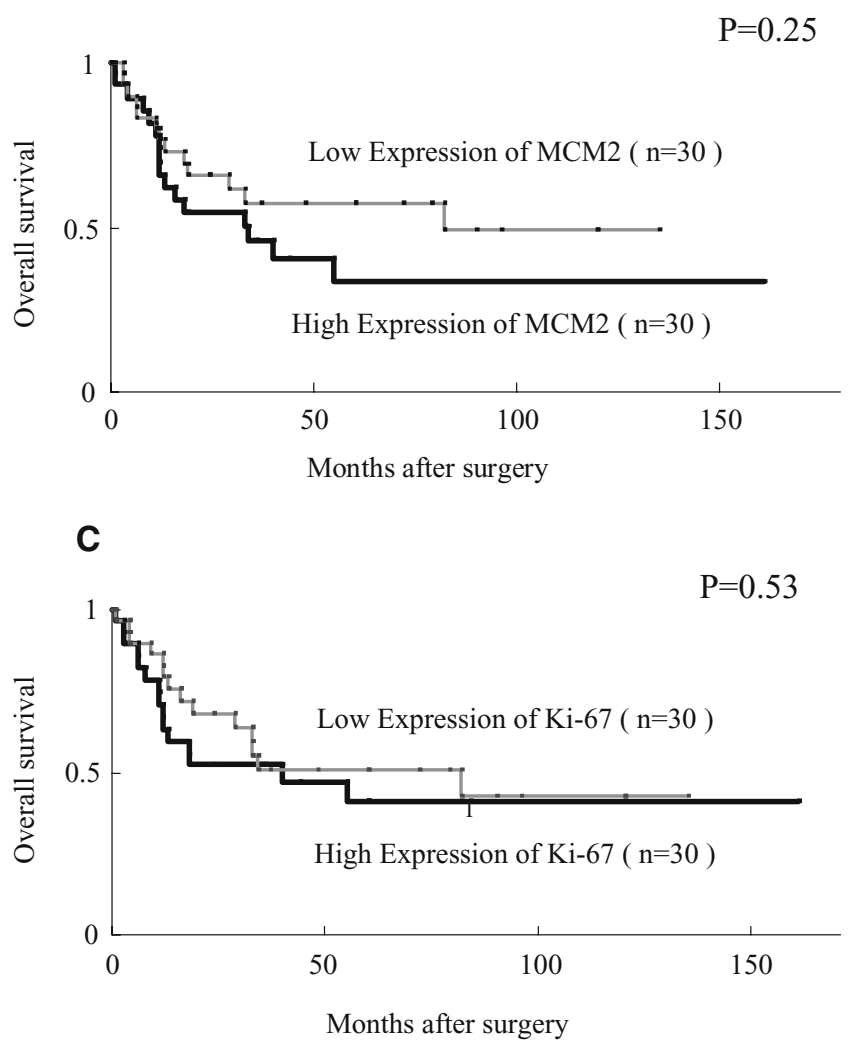

Fig. 6A-D. Association of MCM2 (A, B) and $\mathrm{Ki}-67(\mathbf{C}, \mathbf{D})$ LIs with clinical outcome. Kaplan-Meier survival curves show the survival rates in patients with intestinal-type $(\mathbf{A}, \mathbf{C})$ and diffuse-type (B, D) gastric carcinoma. Among the patients
B

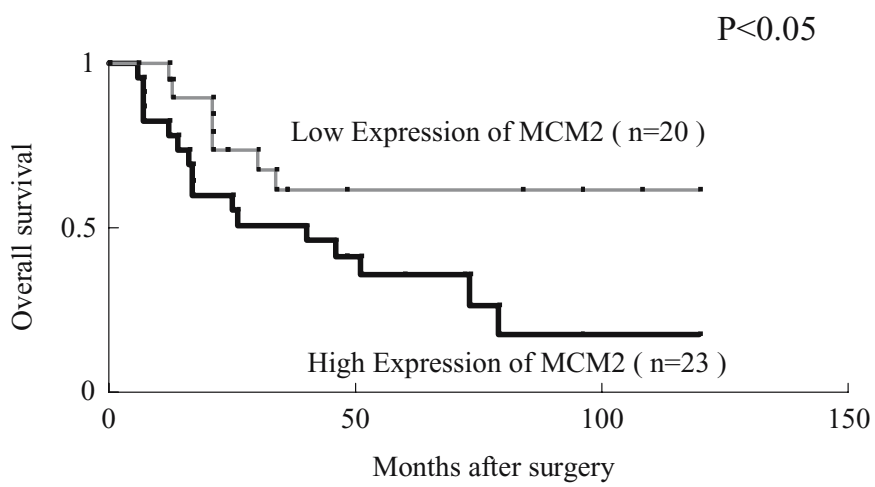

D

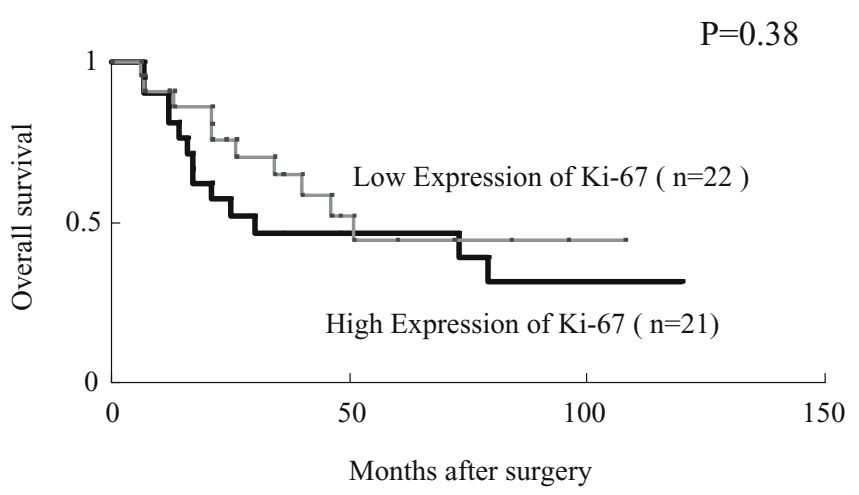

with diffuse-type gastric carcinoma, survival in those with higher MCM2 expression was significantly poorer than the survival in those with lower MCM2 expression $(P<0.05)$

Table 4. Multivariate Cox regression analysis of the contribution of various parameters to overall survival in patients with diffuse-type gastric carcinoma

\begin{tabular}{lccr}
\hline Variable & Risk ratio & $95 \%$ CI & $P$ value \\
\hline MCM2 (high vs low) & 2.654 & $1.073-6.565$ & 0.035 \\
Age ( $\geqq 60$ vs <60 years) & 2.704 & $1.067-6.856$ & 0.036 \\
p53 (high vs low) & 2.082 & $0.888-4.884$ & 0.092 \\
\hline
\end{tabular}

poorer than that in the 20 patients with lower MCM2 expression $(P<0.05$; Fig. 6B). The Ki-67 LI did not correlate with survival in either the patients with intestinal-type $(P=0.53$; Fig. $6 \mathrm{C})$ or in the patients with diffuse-type $(P=0.38)$ carcinomas (Fig. 6D).

Multivariate analysis using the Cox model revealed that MCM2 expression and age were independent prognostic factors in the patients with diffuse-type carcinomas $(P=0.035$ and $P=0.036$, respectively; Table 4$)$.

\section{Discussion}

The new marker MCM2 opens the possibility of evaluating the proliferative activity in a variety of human tumors. MCM2 protein detected by immunohistochemistry can predict the survival of patients with oral or esophageal squamous cell carcinoma $[10,18]$, non-small cell lung cancer [11], breast cancer [19], brain tumor [20, 21], prostate cancer [22], renal cell carcinoma [23], and bladder carcinoma [24]. There have been, however, only a few studies of MCM2 for the assessment of proliferative activity in gastric carcinomas [7,8].

We clearly demonstrated the nuclear expression of MCM2 in human gastric mucosa and carcinoma using a specific anti-MCM2 antibody (2H10). With respect to the expression of MCM2 in normal human stomach tissues, MCM2 expression, as well that of Ki-67, was found in the lower half of the gastric pit, which corresponds to the generative zone. Kato et al. [18] reported 
that MCM2-positive cells were detected in the parabasal layers in human esophageal mucosa. These results suggest that MCM2, as well as $\mathrm{Ki}-67$, is a marker of proliferative cells in human gastric mucosa. Of note, in the present study, MCM2-positive cells were seen sporadically in gastric carcinoma. The LI of MCM2 was significantly associated with that of $\mathrm{Ki}-67$ in gastric carcinoma, but the MCM2 LI was considerably higher. These results are consistent with those of previous studies [11, 18, 25]. Double-labeling immunofluorescence clearly demonstrated that MCM2-positive and Ki-67-negative cells were frequently observed in gastric carcinoma, although mitotic cells did not show MCM2 expression. It is known that $\mathrm{Ki}-67$ is absent in early G1 phase [26]. Thus, we consider that MCM2 expression is seen throughout the cell cycle, except for mitosis and G0 phase, while Ki67 expression is seen from late G1 phase to the mitotic phase. It is also suggested that Ki67 is expressed for a shorter interval of the cell cycle than MCM2 is. Many studies have demonstrated a correlation between the expression of Ki-67 and the number of proliferating cells [27], although the biological function of the Ki-67 antigen remains largely unknown, and the molecule might be not essential for cell proliferation $[28,29]$. The expression level of the Ki-67 antigen can be altered by external factors, such as nutrient deprivation [30]. We also considered that the superior sensitivity of MCM2 over Ki-67 resides in the fact that MCM2 identifies not only cycling cells but also noncycling cells with proliferative potential [9]. Interestingly, the replication phenotype, Ki-67-negative but MCM-positive, is exhibited by premenopausal breast and primary oocytes that retain proliferative capacity and can rapidly respond to growth stimuli [9].

Gastric cancer can be divided into diffuse and intestinal types, according to the Lauren classification [16]. Intestinal carcinomas form recognizable glands that range in histology from tub1 to por1. Diffuse carcinoma consists of poorly cohesive cells diffusely infiltrating the gastric wall, with little or no gland formation. The differences in Ki-67 LIs between the intestinal and diffuse types appear to be very striking compared to the results in previous reports. The striking difference might be due to the method we used for the evaluation of LIs. Counts were performed in high-magnification fields using the FLOVEL Image Filing System FlvFs. With this system, for the evaluation of LIs, we were able to exclude any stromal or inflammatory cells in the field more precisely than with systems used in other studies.

The present study confirmed significantly higher LIs for both MCM2 and Ki-67 in the intestinal-type than in the diffuse-type of stage III gastric carcinomas. Some studies have shown that gastric cancer of the intestinal type had significantly higher proliferative index values, using either Ki-67 [31, 32] or proliferating cell nuclear antigen (PCNA) [33]. This finding was consistent with our results, as we found a correlation between tumor cell proliferation and histological type according to the Lauren classification. In general, diffuse-type carcinoma is considered to be more malignant than its intestinaltype counterpart, with early invasion into the muscularis propria and lymphatic vessels, and metastasis to the lymph nodes [34]. Ikeda et al. [32] reported a relationship between the apoptotic index and the Ki-67 LI in human gastric carcinoma. Their report indicated that intestinal-type gastric carcinoma had a significantly higher apoptotic index as well as a significantly higher Ki-67 LI than the diffuse type. Factors other than the growth fraction (e.g., apoptosis and cell adhesion [35]) may well influence the aggressiveness and dissemination of tumors.

In our present study, although MCM2 expression was significantly associated with Ki-67 in the 43 diffuse-type gastric carcinomas, the survival rate, calculated by the Kaplan-Meier method, revealed a significant inverse correlation between prognosis and the expression of MCM2, whereas the expression of Ki-67 showed no correlation with prognosis. However, MCM2 expression did not correlate with any clinicopathological factors, e.g., lymph node status and vascular invasion, in spite of MCM2 contributing to poor prognosis. This contradiction might be explained, in part, by the fact that our examination focused on only stage III gastric carcinoma. In other words, MCM2 expression might be a more critical factor than any other clinicopathological factors in gastric carcinoma. Taken together, these data suggested that MCM2 was more useful as a prognostic marker than Ki-67 in stage III diffuse-type gastric carcinoma.

We found that age was also an independent prognostic indicator for patients with diffuse-type gastric carcinoma. It has been suggested that age itself is not an independent prognostic survival factor for patients with gastric carcinoma [36, 37]. It is possible that the influence of morbidity factors associated with the aging process on the long-term results might have represented a bias in this study.

Finally, it is worthwhile to touch upon the relationship between MCM2 and p53 expression. Cell-cycleregulated gene sets overlap with proliferation signatures in tumor samples [38]. Gastric cancer cells with overexpression of mutated p53 protein may have high proliferative activity [39]. Kodani et al. [10] have reported that the expression of MCM2 is significantly higher in oral squamous cell carcinomas with high expression of p53 compared to those with low p53 expression, which suggests that MCM2 is correlated with p53 expression. However, in the present study, we could not confirm a significant relationship between MCM2 and p53 LIs in 
either intestinal- or diffuse-type carcinoma. Further studies are needed to clarify the pathobiological significance of any relationship between MCM2 and p53 in human gastric carcinoma.

Acknowledgments The authors thank Mr. N. Itaki, Ms. M. Iwatani, and Ms. T. Yamasaki (Division of Organ Pathology, Faculty of Medicine, Tottori University) for their skillful technical assistance. This work was supported, in part, by a Grant-in Aid for Scientific Research from the Ministry of Education, Culture, Sports, Science and Technology of Japan (Grant No.14370069).

\section{References}

1. Parkin DM, Pisani P, Ferlay J. Estimates of the worldwide incidence of 25 major cancers in 1990. Int J Cancer 1999;80:827-41.

2. Cunningham D, Allum WH, Stenning SP, Thompson JN, Van de Velde CJ, Nicolson M, et al. Perioperative chemotherapy versus surgery alone for resectable gastroesophageal cancer. N Engl J Med 2006;355:11-20.

3. Van Cutsem E, Moiseyenko VM, Tjulandin S, Majlis A, Constenla M, Boni C, et al. Phase III study of docetaxel and cisplatin plus fluorouracil compared with cisplatin and fluorouracil as first-line therapy for advanced gastric cancer: a report of the V325 Study Group. J Clin Oncol 2006;24:4991-7.

4. Dimitrova DS, Prokhorova TA, Blow JJ, Todorov IT, Gilbert DM. Mammalian nuclei become licensed for DNA replication during late telophase. J Cell Sci 2002;115:51-9.

5. Blow JJ, Hodgson B. Replication licensing-defining the proliferative state? Trends Cell Biol 2002;12:72-8.

6. Mendez J, Stillman B. Chromatin association of human origin recognition complex, cdc6, and minichromosome maintenance proteins during the cell cycle: assembly of prereplication complexes in late mitosis. Mol Cell Biol 2000;20:8602-12.

7. Takeda DY, Dutta A. DNA replication and progression through S phase. Oncogene 2005;24:2827-43.

8. Eward KL, Obermann EC, Shreeram S, Loddo M, Fanshawe T, Williams C, et al. DNA replication licensing in somatic and germ cells. J Cell Sci 2004;117:5875-86.

9. Stoeber K, Tlsty T, Happerfield L, Thomas G, Romanov S, Bobrow L. DNA replication licensing and human cell proliferation. J Cell Sci 2001;114:2027-41.

10. Kodani I, Shomori K, Osaki M, Kuratate I, Ryoke K, Ito H: Expression of minichromosome maintenance 2 (MCM2), Ki-67, and cell-cycle-related molecules, and apoptosis in the normaldysplasia-carcinoma sequence of the oral mucosa. Pathobiology 2001;69:150-8.

11. Hashimoto K, Araki K, Osaki M, Nakamura H, Tomita K, Shimizu E, et al. MCM2 and Ki-67 expression in human lung adenocarcinoma: prognostic implications. Pathobiology 2004;71: 193-200.

12. Osaki M, Osaki M, Yamashita H, Shomori K, Yoshida H, Ito H. Expression of minichromosome maintenance-2 in human malignant fibrous histiocytomas: correlations with $\mathrm{Ki}-67$ and p53 expression, and apoptosis. Int J Mol Med 2002;10:161-8.

13. Freeman A, Morris LS, Mills AD, Stoeber K, Askey RA, Williams $\mathrm{GH}$, et al. Minichromosome maintenance proteins as biological markers of dysplasia and malignancy. Clin Cancer Res 1999;5:2121-32.

14. Todorov IT, Werness BA, Wang HQ, Buddharaju LN, Todorova PD, Slocum HK, et al. HsMCM2/BM28:a novel proliferation marker for human tumors and normal tissues. Lab Invest 1998; 78:73-8.
15. Japanese Gastric Cancer Association Registration Committee. Gastric cancer treated in 1991 in Japan: data analysis of nationwide registry. Gastric Cancer 2006;9:51-66.

16. Lauren $P$. The two histological main types of gastric cancer: diffuse and so-called intestinal type carcinoma. An attempt at a histo-clinical classification. Acta Pathol Microbiol Scand 1965; 64:31-49.

17. Japanese Research Society for Gastric Cancer. Japanese classification of gastric carcinoma. Tokyo: Kanehara; 1995.

18. Kato H, Miyazaki T, Fukai Y, Nakajima M, Sohda M, Takita J, Masuda N, et al. A new proliferation marker, minichromosome maintenance protein 2 , is associated with tumor aggressiveness in esophageal squamous cell carcinoma. J Surg Oncol 2003;84:2430.

19. Gonzalez MA, Pinder SE, Callagy G, Vowler SL, Morris LS, Bird $\mathrm{K}$, et al. Minichromosome maintenance protein 2 is a strong independent prognostic marker in breast cancer. J Clin Oncol 2003;21: 4306-13.

20. Hunt DP, Freeman A, Morris LS, Burnet NG, Bird K, Davies $\mathrm{TW}$, et al. Early recurrence of benign meningioma correlates with expression of mini-chromosome maintenance-2 protein. $\mathrm{Br} \mathrm{J}$ Neurosurg 2002;16:10-5.

21. Wharton SB, Chan KK, Anderson JR, Stoeber K, Williams GH. Replicative $\mathrm{Mcm} 2$ protein as a novel proliferation marker in oligodendrogliomas and its relationship to Ki-67 labelling index, histological grade and prognosis. Neuropathol Appl Neurobiol 2001;27:305-13.

22. Meng MV, Grossfeld GD, Williams GH, Dilworth S, Stoeber K, Mulley TW, et al. Minichromosome maintenance protein 2 expression in prostate: characterization and association with outcome after therapy for cancer. Clin Cancer Res 2001;7:2712-8.

23. Rodins K, Cheale M, Coleman N, Fox SB. Minichromosome maintenance protein 2 expression in normal kidney and renal cell carcinomas: relationship to tumor dormancy and potential clinical utility. Clin Cancer Res 2002;8:1075-81.

24. Kruger S, Thorns C, Stocker W, Muller-Kunert E, Bohle A, Feller AC. Prognostic value of MCM2 immunoreactivity in stage T1 transitional cell carcinoma of the bladder. Eur Urol 2003;43: 138-45.

25. Chatrath P, Scott IS, Morris LS, Davies RJ, Rushbrook SM, Bird $\mathrm{K}$, et al. Aberrant expression of minichromosome maintenance protein-2 and $\mathrm{Ki}-67$ in laryngeal squamous epithelial lesions. $\mathrm{Br}$ J Cancer 2003;89:1048-54.

26. Scholzen T, Gerdes J. The Ki67 protein: from the known and the unknown. J Cell Physiol 2000;182:311-22.

27. Brown DC, Gatter KC. Monoclonal antibody Ki-67:its use in histopathology. Histopathology 1990;17:489-503.

28. Verheijen R, Kuijpers HJ, Schlingemann RO, Boehmer AL, van Driel R, Brakenhoff GJ, et al. Ki-67 detects a nuclear matrixassociated proliferation-related antigen: I. Intracellular localization during interphase. J Cell Sci 1989;92:123-30.

29. Verheijen R, Kuijpers HJ, van Driel R, Beck JL, van Dierendonck JH, Brakenhoff GJ, et al. Ki-67 detects a nuclear matrixassociated proliferation-related antigen. II. Localization in mitotic cells and association with chromosomes. J Cell Sci 1989;92: 531-40.

30. Baisch H, Gerdes J. Simultaneous staining of exponentially growing versus plateau phase cells with the proliferation-associated antibody Ki-67 and propidium iodide: analysis by flow cytometry. Cell Tissue Kinet 1987;20:387-91.

31. Müller W, Schneiders A, Meier S, Hommel G, Gabbert HE. Immunohistochemical study on the prognostic value of MIB-1 in gastric carcinoma. Br J Cancer 1996;74:759-65.

32. Ikeda M, Shomori K, Endo K, Makino T, Matssura T, Ito H. Frequent occurrence of apoptosis is an early event in the oncogenesis of human gastric carcinoma. Virchows Arch 1998;43: 43-7.

33. Inada T, Imura J, Ichikawa A, Ogata Y, Shimamura K. Proliferative activity of gastric cancer assessed by immunostaining 
for proliferating cell nuclear antigen. J Surg Oncol 1993;54:14652.

34. Zheng H, Takahashi H, Murai Y, Cui Z, Nomoto K, Miwa S, et al. Pathobiological characteristics of intestinal and diffuse-type gastric carcinoma in Japan: an immunostaining study on the tissue microarray. J Clin Pathol 2007;60:273-7.

35. Hippo Y, Taniguchi H, Tsusumi S, Machida N, Chong JM, Fukayama M, et al. Global gene expression analysis of gastric cancer by oligonucleotide microarrays. Cancer Res 2002;62: 233-40.

36. Llanos O, Butte JM, Crovari F, Duarte I, Guzman S. Survival of young patients after gastrectomy for gastric cancer. World J Surg 2006;30:17-20.
37. Kim DY, Joo JK, Ryu SY, Park YK, Kim YJ, Kim SK. Clinocopathologic characteristics of gastric carcinoma in elderly patients: a comparison with young patients. World J Gastroenterol 2005;11:22-6.

38. Whitfield ML, Sherlock G, Saldanha AJ, Murray JI, Ball CA, Alexander KE, et al. Identification of genes periodically expressed in the human cell cycle and their expression in tumors. Mol Biol Cell 2002;13:1977-2000.

39. Ikeguchi M, Saito H, Kondo A, Tsujitani S, Maeta M, Kaibara N. Mutated p53 protein expression and proliferative activity in advanced gastric cancer. Hepatogastroenterology 1999;46:264853. 